\title{
RELATION OF EXTRAVERSION/INTROVERSION AND FOREIGN LANGUAGE PROFICIENCY IN THE EFL CLASSROOM
}

\author{
Biljana Radić-Bojanić, Department of English Studies, Faculty of \\ Philosophy, University of Novi Sad, Serbia, radic.bojanic@ff.uns.ac.rs
}

Original scientific paper

DOI: 10.31902/fll.33.2020.13

UDC: 811.111:371.3

\begin{abstract}
Apstrakt: Due to the fact that extraverted and introverted personalities are rather different, especially in the context of foreign language learning, teachers and learners often believe that these two personality types have different learning habits and require different learning environments. Moreover, teachers and learners often believe that extraverts are more successful at foreign language learning because they easily communicate in the foreign language and overcome their anxiety without much difficulty. For that reason we aim to determine whether there is a difference between extraverted and introverted students in terms of their foreign language proficiency and in order to establish that we rely on the EPQR-S to determine the students' personality type and the final grade from the previous semester, the grade from the previous English test and the score from the Language and Skills Test to determine the participants' foreign language proficiency. The participants who took part in this research were $\mathrm{N}=60$ first and second grade students from a medical high school in Novi Sad aged 15 to 17 . The results from this research were analyzed quantitatively and, based on the results, we can conclude that introverts are slightly more proficient than extraverted students, but taking into consideration the manner of assessment of English language proficiency, this result must be taken with caution and serves as an indicator of deeper issues that point to the need for a relatively individualized classroom approach in which teachers pay attention to their students' personality and modify their approach to learning and assessment accordingly.
\end{abstract}

Keywords: extraversion, introversion, EFL, language proficiency, high school students.

\section{INTRODUCTION}

For many years, researchers have been interested in the way learners acquire foreign languages, particularly how foreign language learning could be improved. Many studies (e.g. Ellis, 1985; O'Malley et al., 1985; Oxford, 1990; Bachman \& Palmer, 1996; Oxford, 2003) investigated the factors which have an effect on foreign language learning and which 
could facilitate learners' language acquisition and language proficiency. Of the many external and internal factors that play a role in foreign language learning, the most elusive is the factor of the learner's personality and the way its traits contribute to the success in foreign language learning or, on the other hand, how they impede it. As learner personality is an extremely complex phenomenon (cf. Dörnyei, 2005) and includes many different dimensions, we have decided to focus on the dimension of extraversion/introversion since it is the best known one. More precisely, in this paper we will look into how personality traits of extraversion and introversion are related to foreign language proficiency of high school students and what pedagogical implications this connection has by investigating a group of 60 teenagers in a quantitative study.

\section{THEORETICAL FRAMEWORK}

Personality is a very broad construct and it includes a series of features, all of which are seen as a continuum with high and low degrees of presence. One such continuum, that of extraversion/introversion, is easily recognizable because it is manifested in different types of behaviour and reactions to external stimuli. Extraversion is defined as "an attitude type characterized by concentration of interest on the external objects" (Nelson-Jones, 2015: $65)$, i.e. the focus is on the outer world. According to Nelson-Jones (2015), extraverts are believed to be talkative, assertive, gregarious, impulsive and enthusiastic, they like being around other people and taking part in activities which involve socializing. On the other hand, introversion is defined as "an attitude type characterized by orientation in life that particularly values subjective psychic contents" (Nelson-Jones, 2015: 65), i.e. the focus is on one's inner mental activity. For that reason, introverts are seen as quiet, careful, thoughtful and reserved, and they prefer being on their own rather than around other people. Eysenck and Chan (1982) also looked into the extraversion/introversion dimension of personality based on the Myers-Briggs' Type Indicator (MBTI) and their findings were similar: extraverts receive energy from outside sources, whereas introverts thrive on the inner world of ideas.

These characteristics do not have to be used only to describe people's personality, but we can also apply them to learners' behaviour in the classroom and their foreign language learning. As already mentioned, extraverts tend to be talkative, assertive and they enjoy other people's attention. Since they feel energized around others, we can conclude that extraverted learners would much rather 
spend time with other students and do group work than do individual activities. On the other hand, introverted students, who have a rather quiet nature and who are seen as reflexive and reserved, prefer doing individual or perhaps pair work rather than being a part of a big team or interacting with a lot of other students.

Due to the different preferences of these two different personality types, stereotypes mostly occur in terms of learners' foreign language learning abilities and proficiency, particularly concerning introverted students. Namely, because of their shy and reserved personality, introverted students have difficulties participating in classroom activities and tend to be unnoticed by both teachers and other students. On the other hand, because extraverted learners are characterized as open, assertive and talkative, it is generally believed that they score higher on tests or do tasks better that introverts, who are seen as reserved and quiet (e.g. Busch, 1982; Grant \& Cambre, 1990; Müller et al., 2006). However, some studies (e.g. Eysenck \& Eysenck, 1985; Sanchez-Marin et al., 2001) show different results, i.e. indicate that extraverts fail school programs more frequently. In other words, this subject requires a more careful analysis of research done in this field so far.

Firstly, some researchers believe that personality type is not a factor that influences students' language learning and proficiency. For example, Skehan (1989) claims that personality does not play such an important role in language learning as language learning strategies. In addition, research done by Robinson (1985) shows that the dimension of extraversion/introversion is not related to the actual ability of learning, but that it can only be associated with the learners' intellectual style and intelligence profile. In addition, there are studies (e.g. Dreyer \& Van Der Walt, 1994) which show that personality influences language proficiency only indirectly and that it is not an important factor, i.e. that it should not be taken into consideration.

On the other hand, there are researchers who strongly disagree and state that personality influences foreign language learning. Brodkey \& Shore (1976) found that personality was a strong predictor of whether learners would be successful in the process of foreign language learning. Another research study by Nikoopour \& Farsani (2010) confirmed that the dimension of extraversion/introversion is one of the major factors and that it can influence either success or failure in foreign language learning.

However, Eysenck \& Eysenck (1985) suggested that it is not easy to find a strong relationship between personality and educational achievement as there are many factors which can have an additional 
effect, such as the subject studied, the student's gender and motivation, teaching methods and many others. For instance, research studies by Entwistle $(1972)$ and Anthony $(1973,1977)$ showed that, in addition to personality, the learner's age also plays an important role in terms of academic achievement. Namely, these studies suggest that at an earlier age, extraverts have more success in educational achievement. On the other hand, after the age of thirteen, introverted learners are better than extraverts as, after that age, they advance more rapidly. Due to the influence of many factors, studies tend to show different results of extraverts and introverts' language proficiency.

There are studies which support the familiar stereotype about these two personality types and language proficiency. For example, an early study conducted by Busch (1982) showed that extraverted students are more proficient learners. In addition, according to Müller et al. (2006) and Grant \& Cambre (1990), extraversion plays an important role in experience of success in the classroom.

When academic success is concerned, some studies showed that extraversion has a negative effect on it. Namely, it was found that introverted students are much better at revision, that they have a higher ability to learn, and that they outperform extraverts. For example, Eysenck \& Eysenck (1985) suggested that extraverts have difficulty sustaining longer periods of concentration, which is required for successful academic learning. In addition, Sanchez-Marin et al. (2001) offer a similar explanation that extraverts tend to fail their school programmes more frequently due to their distractibility.

Ellis (1994) suggested two hypotheses regarding introversion/extraversion and second language learning. In the first one he stipulates that extraverts are more successful when it comes to acquiring basic interpersonal communication skills. This can be supported by their sociability which encourages them to practice more, to require more input and to be more proficient in communication. On the other hand, the second hypothesis suggests that introverted learners are better at developing cognitive academic language proficiency as they prefer writing and reading skills due to their personality. In another study Ellis (2001) investigated the relationship between personality types and language proficiency and supported one of the hypotheses. This research took into consideration students' success in communication and using and practicing language through communication. In these terms, naturally, it can be concluded that extraverted students are more successful. Namely, as Ellis's study showed, extraverts' essential characteristic, sociability, enables them 
to practice language, as well as to participate more in communication. In addition, this characteristic enables students to both practice and use language outside the classroom, which is essential in achieving fluency. This belief is also supported by Suzić (2017), who explains that introverted students have a higher anxiety level and that it takes them longer to retrieve information. On the other hand, extraverted students, whose anxiety level is lower, are not concerned about making a mistake and are more likely to take risks with their language use.

A number of research studies also investigated conditioning performance of extraverts and introverts. Eysenck (1981) found that introverted students are more likely affected by distractions than extraverts and, secondly, that extraverts' performance is improved when they are rewarded for their work, while the performance of introverted students deteriorates when they are punished or criticized for their work. Furthermore, Gray (1970) and Gupta \& Shukla (1989) received the same results as Eysenck (1981) and indicated that introverts were conditioned better with punishing verbal reinforcement, whereas extraverts were conditioned more with rewarding verbal reinforcement. In other words, these studies indicate that introverted learners are more subject to punishment, while extraverts are more subject to reward, which is something that should be taken into consideration during their learning process.

When information retrieval is concerned, Eysenck (1981) made an observation regarding these two personality types. Extraverts are much faster in retrieving information from long term memory, while introverted learners need more time to retrieve information, especially non-dominant one, from permanent storage. It is possible that this process is affected by anxiety, which affects introverts to a much greater extent than extraverts. Even so, test performance of these two types at long retention intervals shows that introverted students are more successful than extraverts.

\section{METHOD}

Due to varying results in previous research studies we decided to investigate the relation of extraversion/introversion and foreign language proficiency on a sample of teenagers as they are an age group of learners who are undergoing physical development, hormonal changes and cognitive maturement, all of which further reinforce their extraversion or introversion, especially in the educational context. The research was conducted in early 2020 in Novi Sad and it included students of the first and second grades of medical high school with the 
aim to investigate the difference between extraverted and introverted students in terms of foreign language proficiency. The convenient sample of 60 participants who took part in this research were all students in a public medical high school in Novi Sad, Serbia, at the time attending the first $(\mathrm{N}=30)$ and second $(\mathrm{N}=30)$ grades. Their age spanned between 15 and 17 and, being minors, they were asked to have a research consent form signed by their parents. When their English language proficiency is concerned, these students have had English as a compulsory subject since the first grade of primary school, which generally means that in high school they are expected to be at the B1 level of CEFR. However, due to many factors that can affect proficiency, such as language aptitude or motivation, we expected that their English language proficiency would vary to some extent.

For the purpose of this research, the participants were asked for personal information such as their age and the year they attend. In addition, they were asked to provide the grade from the previous semester and the grade from the previous English test and to complete two tests: Eysenck Personality Questionnaire - Revised Short Form Extraversion (EPQR-S) and Language and Skills test. The first instrument constructed by Eysenck et al. (1985) is part of a larger inventory of personality traits and contains 12 items for the subscale of extraversion. Each item was translated into Serbian so that the participants could answer more easily and more accurately. On the basis of their answers the participants were categorized as either extraverts or introverts. The second instrument was used to determine the participants' English language proficiency and was taken from the coursebook that they used in class at their high school (Solutions, intermediate level). The tests differed only in the content due to the fact that the participants' level of proficiency slightly varied - first grade students belonged to B1.1 level and second grade students to the B1.2 level of proficiency. The tests for both groups contained the same number of questions and they both covered the same aspects of language which the participants learnt previously that school year. Both tests contained six tasks with six questions each. There were two tasks which tested participants' knowledge of vocabulary, three tasks concerning their knowledge of grammar and one task that tested their reading skills. For each correct answer participants could get one point, meaning that the highest possible score was 36 points. All grades and test scores were important for the current research study since they were used as a point of comparison with the personality type. All the data collected during the research was then coded and analyzed descriptively. 


\section{RESULTS}

The first relevant piece of information is the number of extraverted and introverted students in the sample and, on the basis of the results of the short form of Eysenck Personality Questionnaire Extraversion, we found that the sample consisted of 46 extraverted students (24 in the first year and 22 in the second year) and 14 introverted students ( 6 in the first year and 8 in the second year). As for the students' English language proficiency, it was observed and measured in several different ways: through the grade they had in the previous semester and in the previous English test, as well as through the score they gained in the Language and Skills Test they were asked to complete. Due to the fact that there were approximately three times more extraverted than introverted participants, we determined the average grade for all of them and calculated the mean, which we then compared. Furthermore, all of the grades and scores were converted into percentage for easier comparison.

The first point of comparison between extraverted and introverted students was the grade they had in the previous semester (see Table 1). The students from both subsamples achieved good results, which is seen in their average grade ( 4.17 for extraverts and 4.50 for introverts), but we can also see that extraverted students had varying final grades, ranging from 2 (sufficient) to 5 (excellent), while introverted students only had two best final grades: 4 (very good) and 5 (excellent).

\begin{tabular}{|l|l|l|l|l|}
\hline Grade & Extraverts & $\%$ & Introverts & $\%$ \\
\hline 1 & 0 & $0 \%$ & 0 & $0 \%$ \\
\hline 2 & 3 & $7 \%$ & 0 & $0 \%$ \\
\hline 3 & 8 & $17 \%$ & 0 & $0 \%$ \\
\hline 4 & 13 & $28 \%$ & 7 & $50 \%$ \\
\hline 5 & 22 & $48 \%$ & 7 & $50 \%$ \\
\hline Mean: & 4.17 & & 4.50 & \\
\hline
\end{tabular}

Table 1. Grades from the previous semester

The second point of comparison was the grade that the students got in their previous English test (see Table 2). Both in the case of extraverts and introverts we can see that the grade they got in their last test was lower than the one from the previous semester. Extraverts had a mean grade of 3.59, while introverts scored a mean grade of 4.00 . When comparing two lower grades ( 2 and 3 ), the data 
shows that introverts have a lower percentage of students with sufficient or good knowledge (7\% and $21 \%$ ) in comparison with extraverts (13\% and $35 \%)$. When grade 4 is concerned, the results of both subsamples are similar (36\% for introverted students and 33\% for extraverts). The most obvious difference can be seen when comparing the number of students with the highest grade, because as many as $36 \%$ of introverts showed excellent knowledge on the last test, whereas only $19 \%$ of extraverts had grade 5 in the last test in English.

\begin{tabular}{|l|l|l|l|l|}
\hline Grade & Extraverts & $\%$ & Introverts & $\%$ \\
\hline 1 & 0 & $0 \%$ & 0 & $0 \%$ \\
\hline 2 & 6 & $13 \%$ & 1 & $7 \%$ \\
\hline 3 & 16 & $35 \%$ & 3 & $21 \%$ \\
\hline 4 & 15 & $33 \%$ & 5 & $36 \%$ \\
\hline 5 & 9 & $19 \%$ & 5 & $36 \%$ \\
\hline Mean: & 3.59 & & 4.00 & \\
\hline
\end{tabular}

Table 2. Grades from the previous semester

The final point of comparison was the Language and Skills Test (see Table 3). Since this test contained two vocabulary tasks, three grammar tasks and one reading task we present results that the students achieved for each of the sections separately and also in total for the entire test in order to make finer distinctions between the two subsamples. If we compare the results from the Language and Skills test for both subsamples, we see that introverts managed to complete the test with a better overall score and that they also had higher average number of points for individual sections than the extraverts.

\begin{tabular}{|l|c|c|}
\hline Type of task & $\begin{array}{c}\text { Average points - } \\
\text { extraverts }\end{array}$ & $\begin{array}{c}\text { Average points - } \\
\text { introverts }\end{array}$ \\
\hline Reading task & 4.52 & 4.93 \\
\hline $\begin{array}{l}\text { Vocabulary tasks } \\
\text { (2) }\end{array}$ & 4.18 & 4.61 \\
\hline Grammar tasks (3) & 3.86 & 4.21 \\
\hline Total average & $24.48(68 \%)$ & $26.79(74 \%)$ \\
\hline
\end{tabular}

Table 3. Average number of points on Language and Skills Test

Since all the results point to the fact that introverted students in the sample analyzed in this paper consistently scored higher in several different means of measuring proficiency, we will further discuss this in the following section. 


\section{DISCUSSION}

Referring back to the studies done by Entwistle (1972) and Anthony $(1973,1977)$, which indicated that the learners' age is an important threshold in the shift of success in foreign language learning between extraverts and introverts, we can say on the basis of our results that the teenagers from the sample indeed do show this change. Namely, learners at an earlier age who are extraverts achieve more success, but as foreign language learning becomes more serious and as the level of proficiency rises, introverts advance better as the tasks are cognitively more demanding and require careful consideration, which is a weak point for extraverted students. In other words, this aspect of our research confirms previous studies and completely falls in line with them.

Additionally, previous research studies both in the field of psychology and education have pointed to the obvious differences between extraverted and introverted students (extraverts are talkative and sociable, while introverts are more quiet, careful and reserved), which also indicate different learning preferences and habits in the foreign language classroom as well. Therefore, the difference between personality types can be applied to learners' behaviour in the classroom, the way they learn the foreign language and the way they use it. Ellis $(1994,2001)$ conducted several research studies to investigate the relationship between extraverts and introverts regarding second language learning and concluded that extraverted learners are better at acquiring basic interpersonal communication skills. Namely, due to their sociability and assertiveness, extraverts practice more and are, therefore, more proficient in communication and speaking skills. In addition, sociability enables extraverts to practice and use the foreign language not only in school, but outside the classroom as well. On the contrary, introverts are characterized as quiet and reserved and do not prefer interacting. Therefore, they do not practice communicating in the foreign language as much as extraverts.

Due to these factors the frequent impression is that extraverts will achieve better results in the foreign language classroom as they are communicative, adaptable and gregarious, whereas the communication in the foreign language causes anxiety for introverts. However, assessment in the EFL classroom is not based only on communicative skills, but also on other demanding cognitive tasks, which is the area in which introverts excel. For example, Ellis (1994, 2000) stipulates that introverts are more successful at developing cognitive academic language proficiency, which is supported by the 
fact that introverts prefer writing and reading skills due to their personality. In other words, introverts excel at tasks in which they can work at their own pace, think quietly and manipulate the material mentally. This essentially explains the difference in our study between the students' higher grades from the previous semester and lower grades they achieved in English language tests, since the final grade is a composite construct that includes both test achievements and communicative tasks that students do during the semester, as well as classroom activity, speaking, projects, homeworks, etc., whereas tests focus more on accuracy in terms of grammar and lexis. However, for all three points of comparison in the current study (grade from the previous semester, grade from the previous test, score from the Language and Skills Test) introverts still have better results that extraverts, most likely because the majority of these scores lean towards accuracy, which is introverts' strong side, much more than towards fluency, which is where extraverts excel.

This also generally indicates certain problems in the assessment of foreign language proficiency in terms of the differences between extraverts and introverts. Namely, the foreign language is primarily learnt to improve communication skills in a variety of contexts, yet assessment is still partly anchored in the traditional grammartranslation method, which focuses much more on accuracy than on fluency. In other words, assessment should be modified and it should strive to achieve a balance between these two, thus providing equal opportunities for extraverts and introverts in terms of the grades they get, which is best achieved by implementing formative assessment (Milošević \& Cvetković, 2019).

In connection with that, efforts should be made on the part of the teacher to reduce anxiety in the classroom, which will help introverts perform better in communicative tasks. As extraverts' anxiety level is lower, they will not find communicative and interactive exercises problematic and difficult, but introverts might have serious issues. Furthermore, Eysenck (1981) made significant conclusions as well. He said that extraverts' performance could be improved by rewarding them for their work, while introverts' performance tends to deteriorate when they are either punished or criticized for their work. Therefore, attention should be paid when rewarding or criticizing learners as these two personality types react differently and as these situations can affect their language learning process.

Taking everything into consideration, we can say that there are certain differences between extraverted and introverted learners regarding their language learning process, but conclusively deciding if 
extraverts or introverts are more proficient in the EFL classroom is a much more complex issue than initially thought. Teachers should pay attention to all of the mentioned aspects in order to facilitate their students' learning process and should balance the process of assessment to give a fair chance to both personality types. Activities in which students participate, their learning environment and teachers' approach can all affect students' learning, i.e. they can be a factor which can determine whether students will be more or less successful at foreign language learning process.

\section{CONCLUSION}

In order to determine the relation between English language proficiency and the personality type of extraverts and introverts we compared their grades from the previous semester, grades from the previous English test, and the score they achieved on the Language and Skills Test. In all three cases introverts scored consistently higher than extraverts (the grade from the previous semester: introverts $M=4.50$, extraverts $M=4.17$; the grade from the previous English test: introverts $M=4.00$, extraverts $M=3.59$; the score on the Language and Skills Test: introverts $M=26.79$, extraverts $M=24.48$ ). Therefore, on the basis of all three points of assessment, we could say introverted learners are somewhat more proficient in English as a foreign language than extraverted learners, but if we take into consideration the fact that assessment of proficiency was done primarily in the manner better suited for introverts, the results should be taken with caution and point to some interesting aspects of the foreign language classroom. Namely, teachers should pay attention and strive to include enough type of activities that both extraverted and introverted learners would be comfortable with. Due to the fact that extraverts are sociable and outgoing, they prefer group work, they function much better in the company of other students as they enjoy other people's attention, and for that reason one part of the class should be devoted to communicative activities that rely on this kind of classroom dynamics. Furthermore, this aspect of classroom work should also be included in assessment, preferably of the formative type, so as to give extraverts a chance to show their strengths in learning English as a foreign language. On the other hand, introverted learners are quiet and passive, which implies they mostly prefer individual activities and sometimes pair work. This also means that introverted students excel at types of tasks where they have enough time to think and answer, without an external pressure to perform immediately. Also, as already suggested in this paper, these are the types of tasks which, in terms of 
assessment, are better suited for introverts. Therefore, teachers should take into consideration the fact that their students are better at certain types of activities depending on their personality and they should help their learners to improve all aspects of the foreign language learning process.

\section{WORKS CITED}

Anthony, W. S. "The development of extraversion, of ability, and of the relation between them." British Journal of Educational Psychology 43 (1973): 223-227.

Anthony, W. S. "The development of extraversion and ability: An analysis of Rushton's longitudinal data." British Journal of Educational Psychology 47 (1977): 193-196.

Bachman, Lyle F., and Palmer, Adrian S. Language testing in practice. New York; Oxford University Press, 1996.

Beaulieu, R. P. "Peak activation time, extraversion, and students' achievement." Perpetual and Motor Skills 73.3 (1991): 1217-1218.

Brodkey, Dean, and Shore, Howard. "Student personality and success in an English language program." Language Learning 26.1 (1976): 153-162.

Busch, Deborah. "Introversion-extraversion and the ESL proficiency of Japanese students." Language Learning 32.1 (1982): 109-132.

Dörnyei, Zoltán. The psychology of the language learner: Individual differences in second language acquisition. Mahwah, NJ: Lawrence Erlbaum, 2005.

Dreyer, Carisma, and Van Der Walt, Johann L. "The significance of learner variables as predictors of ESL proficiency." Studia Anglica Posnaniensia 29(1994): 91-103.

Ellis, Rod. Understanding second language acquisition. Oxford: Oxford University Press. 1985.

Ellis, Rod. The study of second language acquisition. Oxford: Oxford University Press, 1994.

Ellis, Rod. Form-focused instruction and second language learning. Malden, MA: Blackwell, 2001.

Entwistle, N. J. "Personality and academic attainment." British Journal of Educational Psychology 42 (1972): 137-151.

Eysenck, Hans J., and Eysenck, Michael W. Personality and individual differences. New York: Plenum, 1985.

Eysenck, Michael W. "Learning, memory, and personality." A model for personality. Ed. Hans J. Eysenck. New York: Springer, New York, 1981. 169-209. 
Eysenck, Sybil B., and Chan, Jimmy. "A comparative study of personality in adults and children: Hong Kong vs. England." Personality and individual differences 3.2 (1982): 153-160.

Grant, Martha, and Cambre, Marjorie. 'Research on teachers' characteristics in relation to a cognitive-learning based interactive videodisc system." Computer Science (1990). Retrieved September 4, 2020 from https://www.learntechlib.org/p/141641/.

Gray, Jeffrey A. "The psychophysiological basis of introversionextraversion." Behaviour Research and Therapy 8.3 (1970): 249266.

Gupta, Sunita, and Shukla, A. P. "Verbal operant conditioning as a function of extraversion and reinforcement." British Journal of Psychology 80 (1989): 39-44.

Milošević, Olja, and Cvetković, Marina. "Impact of formative assessment on the confidence of young learners in the second language classroom." Metodički vidici 10 (2019): 139-150.

Müller, Florian H., et al. "Personality, motives and learning environment as predictors of self-determined learning motivation." Review of Psychology 13.2 (2006): 75-86.

Nelson-Jones, Richard. Nelson-Jones' Theory and Practice of Counselling and Psychotherapy. Los Angeles: Sage Publications, 2015.

Nikoopour, Jahanbakhsh, and Farsani, Mohammad Amini. "On the relationship between language learning strategies and personality types among Iranian EFL learners." Journal of English Studies 1.1 (2010), 81-101.

O'Malley, Michael J., et al. "Learning strategies used by beginning and intermediate ESL students." Language Learning 35.1 (1985), 2146.

Oxford, Rebecca L. Language learning strategies: What every teacher should know. New York: Newbury House Publishers, 1990.

Oxford, Rebecca L. Language learning styles and strategies. Berlin: Mouton de Gruyter. 2003.

Robinson, David L. "How personality relates to intelligence test performance: Implications for a theory of intelligence, ageing research and personality assessment." Personality and Individual Differences 6.2 (1985): 203-216.

Sanchez-Marin, Manuel, et al. "Personality and academic productivity in the university student." Social Behavior and Personality 29.3 (2001), 299-306.

Skehan, Peter. Individual differences in second language learning. London: Edward Arnold, 1989. 
Suzić, Radmila. "Jezička anksioznost i anksioznost pri komunikaciji na stranom jeziku u razrednoj situaciji." Metodički vidici 7 (2017): 347-363.

\section{ODNOS EKSTRAVERZIJE/INTROVERZIJE I NIVOA ZNANJA ENGLESKOG JEZIKA KAO STRANOG}

$S$ obzirom na to da su ekstravertne $i$ introvertne ličnosti veoma različite, naročito u nastavi stranih jezika, nastavnici i učenici često veruju da ova dva tipa ličnosti imaju različite navike u učenju i da su im stoga potrebne različite okolnosti za učenje. Štaviše, nastavnici i učenici često veruju da su ekstravertne ličnosti uspešnije u učenju stranog jezika, jer lako komuniciraju na stranom jeziku i prevazilaze anksioznost bez mnogo poteškoća. Iz tog razloga u ovom radu želimo da utvrdimo da li postoje razlike između ekstravertnih i introvertnih učenika u pogledu nivoa znanja stranog jezika i, da bismo to utvrdili, oslonili smo se na rezultate skraćenog testa ličnosti koji ispituje jednu od dimenzija, ekstravertnost (EPQR-S), i ocenu iz prethodnog polugodišta, ocenu sa poslednjeg testa iz engleskog jezika i rezultat koji su ispitanici postigli na testu veština i znanja jezika. $U$ istraživanju je učestvovalo $N=60$ učenika prvog i drugog razreda srednje medicinske škole u Novom Sadu starih između 15 i 17 godina. Rezultati dobijeni u ovom istraživanju analizirani su kvantitativno i na osnovu njih možemo da zaključimo da introvertni učenici pokazuju nešto viši nivo znanja od ekstravertnih, ali ako uzmemo u obzir način merenja nivoa znanja engleskog jezika, ovaj rezultat moramo da uzmemo sa izvesnom rezervom. Naime, on je u stvari pokazatelj potrebe za relativno individualizovanim pristupom nastavi stranih jezika, u kome nastavnik treba da uzme u obzir ličnost učenika i u skladu sa time da prilagodi nastavni pristup i metode ocenjivanja.

Ključne reči: ekstraverzija, introverzija, engleski jezik kao strani, nivo znanja, srednješkolci. 